\title{
Azoto trąšų poveikis skirtingų žieminių kviečių veislių fotosintetiniams rodikliams
}

\author{
Aistė Juchnevičienè $\dot{1}^{1}$ \\ Ilona Vagusevičiené ${ }^{1}$, \\ Aušra Kaminskaitè ${ }^{1}$, \\ Aušra Brazaityté丶 \\ Pavelas Duchovskis ${ }^{1,2}$ \\ ${ }^{1}$ Aleksandro Stulginskio universitetas, \\ Studentu g. 11, \\ LT-53361 Akademija, Kauno r. \\ El.paštas: aiste.zuzaviciute@inbox.lt \\ ${ }^{2}$ Lietuvos agrariniu ir mišku \\ mokslu centras, \\ Instituto al. 1, LT-58344 Kédainių r.
}

Darbe tirtas azoto trąšų poveikis skirtingų žieminių kviečių veislių fotosintetinių rodiklių dinamikai. Lauko eksperimentas vykdytas 2012-2013 m. Aleksandro Stulginskio universiteto Bandymų stotyje, karbonatingame sekliai glejjiškame išplautžemyje Calc(ar)i-Epihypogleyic Luvisol. Tyrimo objektas - gerų kepimo savybių žieminių kviečių veislès 'Kovas', 'Olivin'. Sejjos metu kviečiai buvo tręšti vienanaremis fosforo, kalio trąšomis $\left(\mathrm{P}_{60} \mathrm{~K}_{60}\right)$, o pavasarị, atsinaujinus vegetacijai, - amonio salietra $\left(\mathrm{N}_{60}\right)$. Papildomai per lapus tręšti karbamido tirpalu $\left(\mathrm{N}_{30}\right.$, $\left.\mathrm{N}_{40}\right)$ bamblëjimo ir $\left(\mathrm{N}_{15}, \mathrm{~N}_{30}\right)$ pieninès brandos tarpsniais. Tyrimų metu nustatyta, kad papildomas tręšimas $\mathrm{N}_{30}$ ir $\mathrm{N}_{40}$ azoto normomis vèlyvaisiais augalo vystymosi tarpsniais skatino fotosintezės pigmentų kaupimąsi ir prailgino aktyvios fotosintezès periodą. Veislès genetiniai ypatumai turèjo ịtakos pigmentų kaupimuisi nepriklausomai nuo tręšimo azoto trąšomis. Gerų kepimo savybių kviečių veislè 'Kovas' linkusi kaupti didesnius fotosintezės pigmentų kiekius. Didžiausias pigmentų kiekis nustatytas pieninès brandos pradžioje prieš papildomą tręšimą $\mathrm{N}_{15}, \mathrm{~N}_{30}$ trąšų normomis. 'Olivin' veislès žieminiai kviečiai turi didesni grynąji fotosintezės produktyvumo potencialą nei 'Kovas' veislès kviečiai. Intensyviausiai ‘Olivin’ veislès augalų fotosintezė vyko nuo vamzdelëjimo iki pieninès brandos tarpsnio (BBCH 43-74), tręšiant $\mathrm{N}_{60}+\mathrm{N}_{40}$, o 'Kovas' veislès kviečių $-\mathrm{N}_{60}+\mathrm{N}_{30}$ azoto normomis.

Raktažodžiai: azoto trąšos, fotosintezès pigmentai, grynasis fotosintezès produktyvumas, žieminių kviečių veislès

\section{IVADAS}

Fotosintezès pigmentų (chlorofilų $a, b$, karotenoidų) sudètis atspindi bendrą augalo būklę, jo potencialą vykdyti fotosintezę, leidžia ịvertinti ir prognozuoti agrotechnologijų efektyvumą (Bojovic, Stojanovic, 2005). Tik optimalus pigmentų kiekis ir santykis užtikrina efektyvų fotosintezès aparato darbą (Scebba et al., 2003; Sakalauskienè ir kt., 2008; 2009). Reikètų atkreipti dèmesị $\mathfrak{i}$ tai, kad pigmentų kiekis augaluose priklauso nuo genetinių veiksnių, augimo ir vystymosi procesų vyksmo, aplinkos sąlygų (Bojovic, Stojanovic, 2005), pasèlio tankumo (Samborski et al., 2009). Šiltejant klimatui keičiasi temperatūros ir drègmès režimai, kurie taip pat smarkiai veikia fotosintezès procesą ir augalų chlorofilo kie- ki (Guo et al., 2006; Kim et al., 2007; Guo et al., 2008). Dél klimato kaitos patiriamus derliaus nuostolius galime sumažinti, tinkamai parinkdami augalus ar jų veisles, taikydami atitinkamas auginimo technologijas (Brazaityte ir kt., 2008; Duchovskis ir kt., 2015).

Chlorofilai ypač jautriai reaguoja į azoto kiekio dirvoje pasikeitimus (Kopsell et al., 2004). Tręšimas azoto trąšomis skatina fotosintetinio aparato veiklą, palaiko tinkamą chlorofilų $a$ ir $b$ santyki, skatina augimą bei lètina vystymąsi (Kopsell et al., 2004; Tranavičienè et al., 2007; Šlapakauskas, Duchovskis, 2008). Atlikta nemažai tyrimų, kuriuose chlorofilų kiekiai taikomi kaip rodikliai tręšimo technologijoms optimizuoti (Bojovic, Stojanovic, 2005; Cartelat et al., 2005; Spaner et al., 2005; Kichey et al., 2006; Fritchi, Ray, 2007; Houles et al., 
2007). Nuo plaukejimo tarpsnio pabaigos, prasidèjus senėjimo procesams, chlorofilų sistema nèra tinkamas azoto mitybos indikatorius ( $\mathrm{Li}$ et al., 2006; Wingler et al., 2006).

Augalo poreikis azotui ir maksimalus derlius yra genetiškai užprogramuoti (Balogh et al., 2007). Javų produktyvumas ir derliaus formavimas yra agroklimatinių veiksnių, technologinių priemonių ir genotipo nulemtų morfologinių ir fiziologinių ypatumų (fotosintezès ir kvépavimo intensyvumas, asimiliuojančio lapų ploto dydis, maisto medžiagų ìsisavinimo efektyvumas, asimiliatų pasiskirstymas augale), lemiančiu augalo fotosintezès potencialą, tarpusavio sąveikos išdava (Diekmann, Fishbeck, 2005; Šlapakauskas, Duchovskis, 2008). Priklausomai nuo aplinkos sąlygų tinkamai parinkta tręšimo schema atideda pigmentų degradaciją, prailgina aktyvų fotosintezès periodą, užtikrina efektyvesnị asimiliatų transportavimą ị sèklas, nuo to priklauso derlius (Tranavičienè, 2009).

Darbo tikslas - ištirti azoto trąšų poveiki skirtingų žieminių kviečių veislių fotosintetinių rodiklių dinamikai.

\section{TYRIMŲ METODAI IR SĄLYGOS}

Tyrimai atlikti 2012-2013 m. Aleksandro Stulginskio universiteto Bandymų stotyje. Tirtos geras kepamąsias savybes turinčios žieminių kviečių veislès: 'Kovas' (Lietuva) ir 'Olivin' (Jungtinès Amerikos Valstijos). Dirvožemis - karbonatingas sekliai glejiškas išplautžemis (IDg8-k), pagal FAO klasifikaciją Calc(ar)i-Epihypogleyic Luvisol $(L V g-p-w-c c)$ (Lietuvos dirvožemiai, 2001). Dirvos ariamasis sluoksnis silpnai šarminis $\left(\mathrm{pH}_{\mathrm{KCl}} 7,2\right)$, vidutinio humusingumo (2,48 \%), didelio fosforingumo $\left(271,0 \mathrm{mg} \mathrm{kg} \mathrm{m}^{-1} \quad \mathrm{P}_{2} \mathrm{O}_{5}\right)$ ir kalingas (184,0 $\left.\mathrm{mg} \mathrm{kg}^{-1} \mathrm{~K}_{2} \mathrm{O}\right)$. Lauko eksperimentas įrengtas keturiais pakartojimais. Bendras laukelio plotas $-40 \mathrm{~m}^{2}$, apskaitomojo $-20 \mathrm{~m}^{2}$. Laukeliai išdèstyti atsitiktine tvarka.

Žieminių kviečių priešsèlis - žieminiai rapsai. Pagrindiniai darbai įrengiant eksperimentą: rudeninis arimas, kultivavimas, akejjimas, sejja ir trąšuc itterpimas. Séklos norma $-4,5 \mathrm{mln}$. ha-1 daigių sèklų. Vienanarès fosforo ir kalio $\left(\mathrm{P}_{60} \mathrm{~K}_{60}\right)$ trąšos išbertos séjos metu, o amonio salietra $\left(\mathrm{N}_{60}\right)$ - anksti pavasarị, atsinaujinus žieminių kviečių vegetacijai (BBCH 23-25). Papildomai per lapus tręšta karbamido tirpalu: $\mathrm{N}_{30}$ ir $\mathrm{N}_{40}$ - bamblejjimo (BBCH 34-
36) ir $\mathrm{N}_{15}, \mathrm{~N}_{30}$ - pieninès brandos (BBCH 71-74) tarpsniais.

Eksperimento schema:

1. Kontrolè (Fonas) $-\left(\mathrm{P}_{60} \mathrm{~K}_{60}\right)-$ sejjos metu + $\mathrm{N}_{60}$ - krūmijimosi tarpsniu.

2. Fonas $+\mathrm{N}_{60}-$ krūmijimosi tarpsniu $+\mathrm{N}_{30}-$ bamblejimo tarpsniu $+\mathrm{N}_{15}$ - pieninès brandos tarpsniu.

3. Fonas $+\mathrm{N}_{60}-$ krūmijimosi tarpsniu $+\mathrm{N}_{30}-$ bamblejimo tarpsniu $+\mathrm{N}_{30}$ - pieninès brandos tarpsniu.

4. Fonas $+\mathrm{N}_{60}-$ krūmijimosi tarpsniu $+\mathrm{N}_{40}-$ bamblejimo tarpsniu $+\mathrm{N}_{15}$ - pieninès brandos tarpsniu.

5. Fonas $+\mathrm{N}_{60}-$ krūmijimosi tarpsniu $+\mathrm{N}_{40}-$ bamblëjimo tarpsniu $+\mathrm{N}_{30}$ - pieninès brandos tarpsniu.

Taikyta intensyvi augalų apsaugos nuo kenkejjų ir ligų sistema. Daigų tarpsnio pabaigoje - krūmijimosi pradžioje (BBCH 19-20) javai nupurkšti herbicidu Arrat 0,2 $\mathrm{kg} \mathrm{ha}^{-1}$. Bamblèjimo pabaigoje (BBCH 37) naudotas fungicidas Allegro Super 0,75 $1 \mathrm{ha}^{-1}+$ augimo reguliatorius Medax Top $0,75 \mathrm{l} \mathrm{ha}^{-1}$, žydejimo viduryje (BBCH 65) - fungicidas Prosaro ${ }^{\circledR} 250$ EC 1,0 1 ha $^{-1}$.

Dirvožemio agrocheminès analizès atliktos šiais metodais: $\mathrm{pH}_{\mathrm{KCl}}$ - potenciometriniu, $1 \mathrm{~N} \mathrm{KCl}$ ištraukoje; organinè anglis $(\mathrm{C}), \%$ - Tiurino metodu; humusas, \% - apskaičiuotas anglies kieki padauginus iš koeficiento 1,724 ; judrieji fosforas $\left(\mathrm{P}_{2} \mathrm{O}_{5}\right)$ ir kalis $\left(\mathrm{K}_{2} \mathrm{O}\right)$, $\mathrm{mg} \mathrm{kg}^{-1}$ - Egnerio-Rimo-Domingo (A-L) metodu.

Kviečių vystymosi tarpsniai pateikti pagal BBCH skalę (Meier, 1997).

Fotosintezès pigmentų (chlorofilų $a, b$ ir karotenoidų) kiekis žalioje lapų maseje nustatytas $100 \%$ acetono ekstrakte spektrofotometriniu D. Vetšteino (Wettstein) metodu, spektrofotometru „Genesys 6“ („ThermoSpectronic“, JAV) (Gavrilenko, Zhygalova, 2003).

Asimiliacinis lapų plotas matuotas lapų ploto matuokliu WinDias (Delta-T Devices, Jungtine Karalystè). Sausų medžiagų kiekis įvertintas išdžiovinus žaliąją masę $+105{ }^{\circ} \mathrm{C}$ temperatūroje iki pastovios masès.

Grynasis fotosintezės produktyvumas $\left(F_{p r}\right)$ apskaičiuotas pagal formulę:

$$
F_{p r}=2\left(M_{2}-M_{1}\right) /\left(L_{1}+L_{2}\right) T
$$


$\left(M_{2}-M_{1}\right)-$ sausų medžiagų padidejimas per tam tikrą laiką, $L_{1}$ ir $L_{2}$ - lapų plotas laikotarpio pradžioje ir pabaigoje, $T$ - laiko trukmé paromis (Bluzmanas ir kt., 1991).

Tyrimai atlikti skirtingais kviečių augimo tarpsniais, prieš ir po kiekvieno tręšimo azoto trąšomis.

Meteorologinès sąlygos apibūdintos remiantis Kauno meteorologinès stoties Noreikiškèse registruotais duomenimis. $2012 \mathrm{~m}$. kviečiai buvo pasèti rugsèjo 17 dieną. Vidutiné rugsèjo ménesio oro temperatūra buvo artima daugiametei $-12,2{ }^{\circ} \mathrm{C}$. Mènesio kritulių kiekis 13,2 mm viršijo daugiametị rugsejo mèn. vidurkị (1 pav.)

Žiemkenčiai gerai ir tolygiai sudygo, įsišaknijo ir jų vegetacija tęsèsi iki lapkričio vidurio. Nors žiema nebuvo šilta, pasèlis peržiemojo gerai. Augalų vegetacija atsinaujino balandžio viduryje. Vidutinè balandžio mèn. oro temperatūra siekè $5,5{ }^{\circ} \mathrm{C}\left(1,2{ }^{\circ} \mathrm{C}\right.$ žemesnè už daugiametę), kritulių iškrito $56,5 \mathrm{~mm}$. Gegužès mèn. buvo šiltas ir drègnas (HTK - 1,28). Vidutinè oro temperatūra siekè $16,1{ }^{\circ} \mathrm{C}\left(3,5^{\circ} \mathrm{C}\right.$ aukštesnè už daugiametę). Birželio mèn. vidutinè oro temperatūra buvo $18,5{ }^{\circ} \mathrm{C}$ (artima daugiametei). Aukščiausia oro temperatūra $-23,9^{\circ} \mathrm{C}$. Kritulių per mènesị iškrito $45,9 \mathrm{~mm}$ (HTK - 0,83). Liepos mèn. orai buvo permainingi. Pirmąji liepos dešimtadienị kritulių iškrito tik $1,5 \mathrm{~mm}$, o vidutinè oro temperatūra siekè $19,1^{\circ} \mathrm{C}$. Antrąji dešimtadienị smarkiai lijo $(79,8 \mathrm{~mm})$, vi- dutinè oro temperatūra $-17,6{ }^{\circ} \mathrm{C}$. Trečiajj dešimtadienị krituliu iškrito $37,2 \mathrm{~mm}$, vidutinè oro temperatūra pakilo iki $19,1^{\circ} \mathrm{C}$.

Tyrimų duomenys įvertinti koreliacinès analizès metodais naudojant STAT_ENG iš programinio paketo Selekcija (Tarakanovas, Raudonius, 2003). Paveiksluose pavaizduoti vidurkiai ir standartiniai nuokrypiai apskaičiuoti biometrinèms analizems rekomenduojamais metodais (Sokal, Rohlf, 2000).

\section{TYRIMŲ REZULTATAI}

Fotosintezė yra vienas pagrindinių fiziologiniu procesų, lemiančių augalų produktyvumą. Efektyvią fotosintezès veiklą užtikrina tinkamas chlorofilų kiekis ir santykis (Scebba et al., 2003; Sakalauskienè ir kt., 2008; 2009). Siekiant nustatyti azoto trąšų normų poveikį skirtingų veislių žieminiams kviečiams, buvo įvertinti svarbiausi fotosintezès funkcionavimą ir produktyvumą lemiantys rodikliai - fotosintezès pigmentai (chlorofilas $a$ ir $b$, karotenoidai) bei jų pokyčiai vegetacijos metu.

Išanalizavus duomenis pastebèta, kad žieminių kviečių veislè 'Kovas' linkusi kaupti daugiau fotosintezès pigmentų, palyginti su 'Olivin' veisle (2 pav.).

Atsinaujinus vegetacijai augalų lapuose pradèjo didèti fotosintezès pigmentų (chlorofilo $a$, $b$ ir karotenoidų) kiekiai. Krūmijimosi tarpsniu

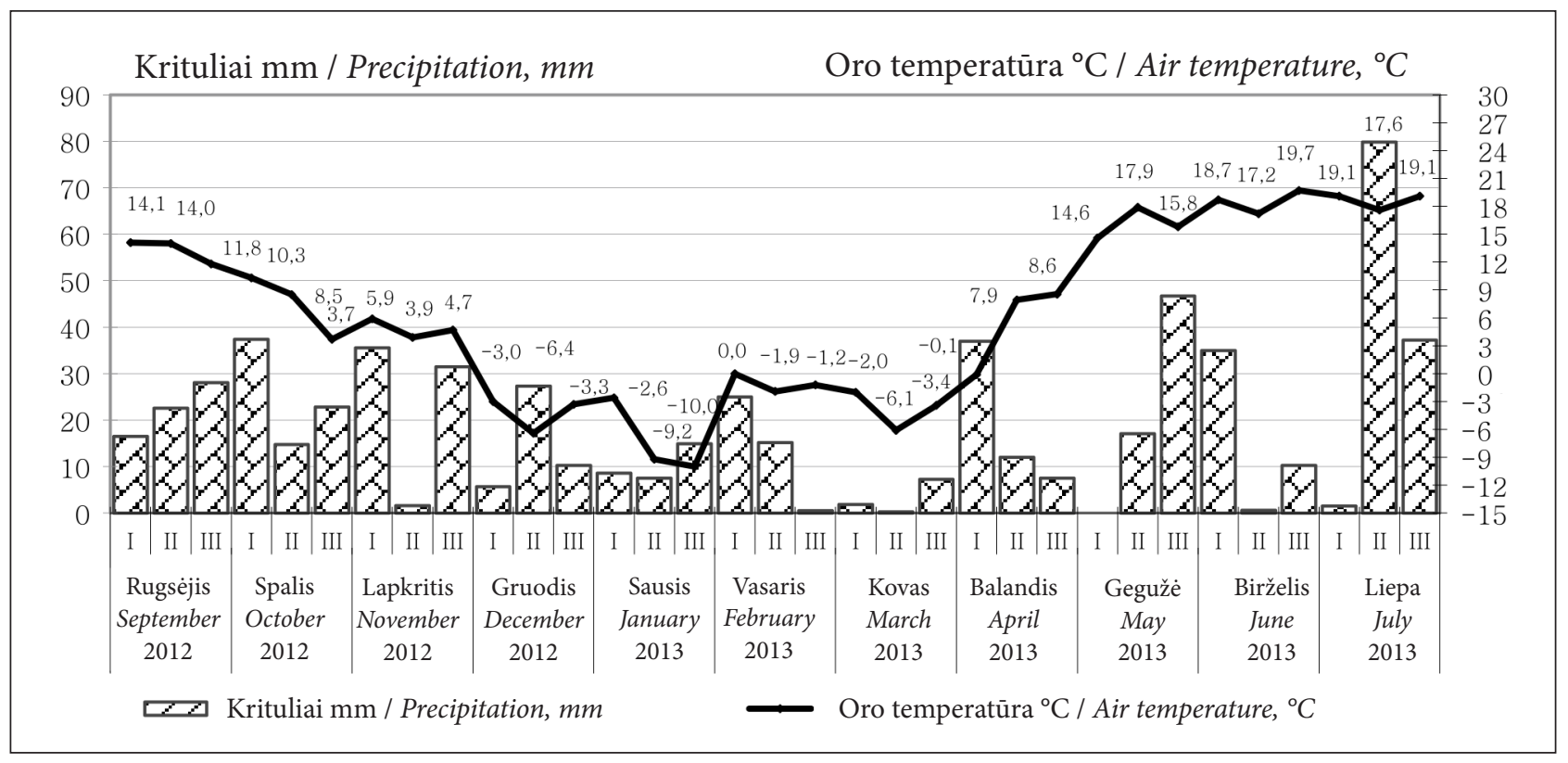

1 pav. Meteorologinès sąlygos žieminių kviečių vegetacijos metu, 2012-2013 m. (Kauno meteorologinè stotis)

Fig. 1. Meteorological conditions during the winter wheat growing period, 2012-2013 (Kaunas Meteorological Station) 


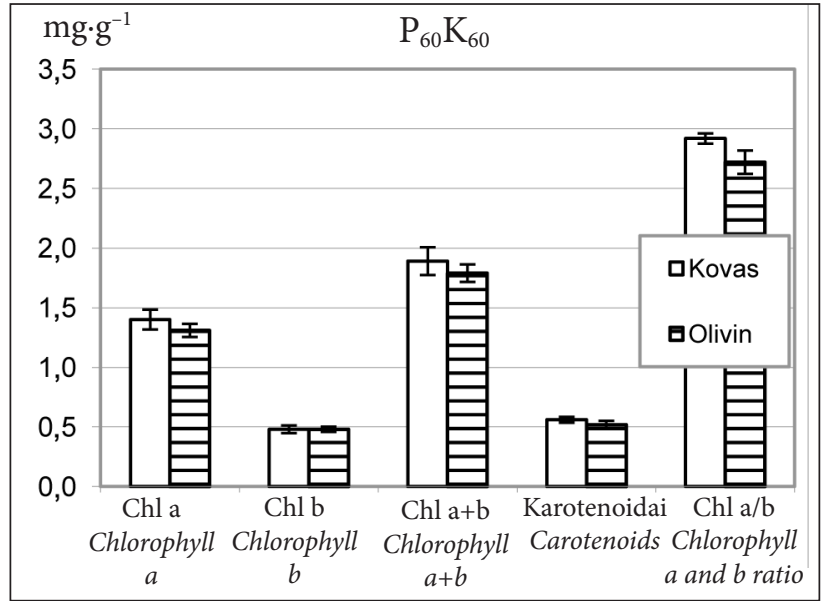

2 pav. Fotosintezès pigmentų kiekis žieminių kviečių lapuose prieš pagrindinị tręšimą (BBCH 23-25)

Fig. 2. The content of photosynthetic pigments in the winter wheat leaves before the main fertilization ( $\mathrm{BBCH} 23-25)$

(BBCH 23) prieš pagrindinị tręšimą $\mathrm{N}_{60}$ azoto norma didžiausias chlorofilo $a$ kiekis buvo nustatytas kviečių veislès 'Kovas' (1,40 $\left.\mathrm{mg} \mathrm{g}^{-1}\right)$ lapuose ir kiek mažesnis - 'Olivin' (1,31 $\left.\mathrm{mg} \mathrm{g}^{-1}\right)$ lapuose. Chlorofilo $b$ ir karotenoidų kiekių pokyčiai abiejų veislių lapuose - nežymūs. Chlorofilų $a / b$ santykis prieš panaudojant $\mathrm{N}_{60}$ trąšų normą 'Kovas' $(2,92)$ veislès kviečiuose buvo žymiai didesnis, palyginti su 'Olivin’ $(2,72)$ veisle. Mažesnis kaip 3 chlorofilų $a / b$ santykis rodo, kad žiemojimo nepalankūs veiksniai veikia kaip stresoriai. Atsižvelgiant $\mathfrak{i}$ gautus rezultatus dar galima teigti, kad šiems fotosintezès pigmentų svyravimams turèjo ịtakos veislès genetinès savybès.

Pavasarị atlikus pagrindinị tręšimą pastebèta ta pati tendencija kaip ir prieš trę̌simą - veisle 'Kovas' (chlorofilas $a-1,38 \mathrm{mg} \mathrm{g}^{-1}$, chlorofilas $b-0,56 \mathrm{mg} \mathrm{g}^{-1}$ ) linkusi kaupti daugiau fotosintezès pigmentų nei veisle 'Olivin' (chlorofilas $a-1,30 \mathrm{mg} \mathrm{g}^{-1}$, chlorofilas $b-0,48 \mathrm{mg} \mathrm{g}^{-1}$ ) (3 pav.).Palyginus chlorofilo $a, b$ ir karotenoidų kiekius prieš ir po tręšimo $\mathrm{N}_{60}$ azoto norma matome, kad jie kito nežymiai. Tačiau chlorofilų $a / b$ santykis, kuris geriausiai atspindi augalo būklę, tiek 'Kovas', tiek 'Olivin' kviečių veislių lapuose po tręšimo buvo sumažèjęs.

Bamblejimo tarpsniu (BBCH 34) prieš papildomą tręšimą žieminiai kviečiai jau buvo pradèję intensyviai kaupti fotosintezès pigmentus (4 pav.).

Lemiamos ịtakos fotosintezès pigmentų kaupimui augaluose turejjo kviečių genotipas. Veislè 'Kovas' (chlorofilas $a-1,58 \mathrm{mg} \mathrm{g}^{-1}$, karotenoidai - 0,71 $\mathrm{mg} \mathrm{g}^{-1}$ ) sukaupe žymiai didesnị chlorofi-

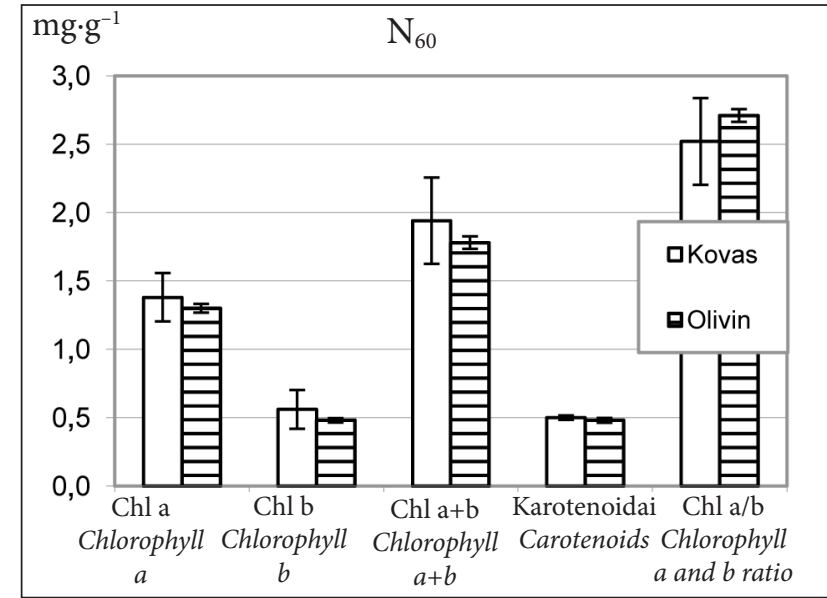

3 pav. Fotosintezės pigmentų kiekis žieminių kviečių lapuose po pagrindinio tręšimo (BBCH 25-28)

Fig. 3. The content of photosynthetic pigments in the winter wheat leaves after the main fertilization ( $\mathrm{BBCH} 25-28)$

lo $a$ ir karotenoidų kieki nei veislè 'Olivin' (chlorofilas $a-1,37 \mathrm{mg} \mathrm{g}^{-1}$, karotenoidai $-0,59 \mathrm{mg} \mathrm{g}^{-1}$ ). Chlorofilo $b$ didžiausias kiekis nustatytas 'Kovas' $\left(0,53 \mathrm{mg} \mathrm{g}^{-1}\right)$ veislès augaluose ir kiek mažesnis - 'Olivin' $\left(0,47 \mathrm{mg} \mathrm{g}^{-1}\right)$.

Bamblejjimo tarpsniu (BBCH 36) netręšti ir papildomai tręšti $\mathrm{N}_{40}$ azoto norma 'Kovas' veislès kviečiai kaupè daugiau fotosintezès pigmentų, palyginti su kita kviečiu veisle. Tačiau papildomam tręšimui panaudojus $\mathrm{N}_{30}$ trąšų normą, 'Kovas' veislès augaluose pigmentų susikaupè mažiau nei 'Olivin' augaluose (5 pav.).

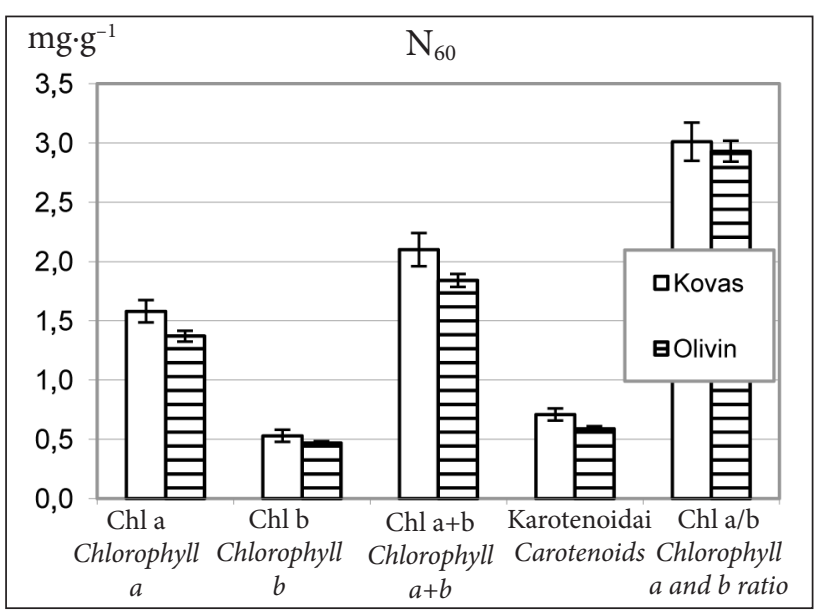

4 pav. Fotosintezès pigmentų kiekis žieminių kviečių lapuose prieš papildomą tręšimą (BBCH 34-36) karbamido tirpalais $\mathrm{N}_{30}$ ir $\mathrm{N}_{40}$

Fig. 4. The content of photosynthetic pigments in the winter wheat leaves before additional fertilization (BBCH 3436) with urea solutions $N_{30}$ and $N_{40}$ 


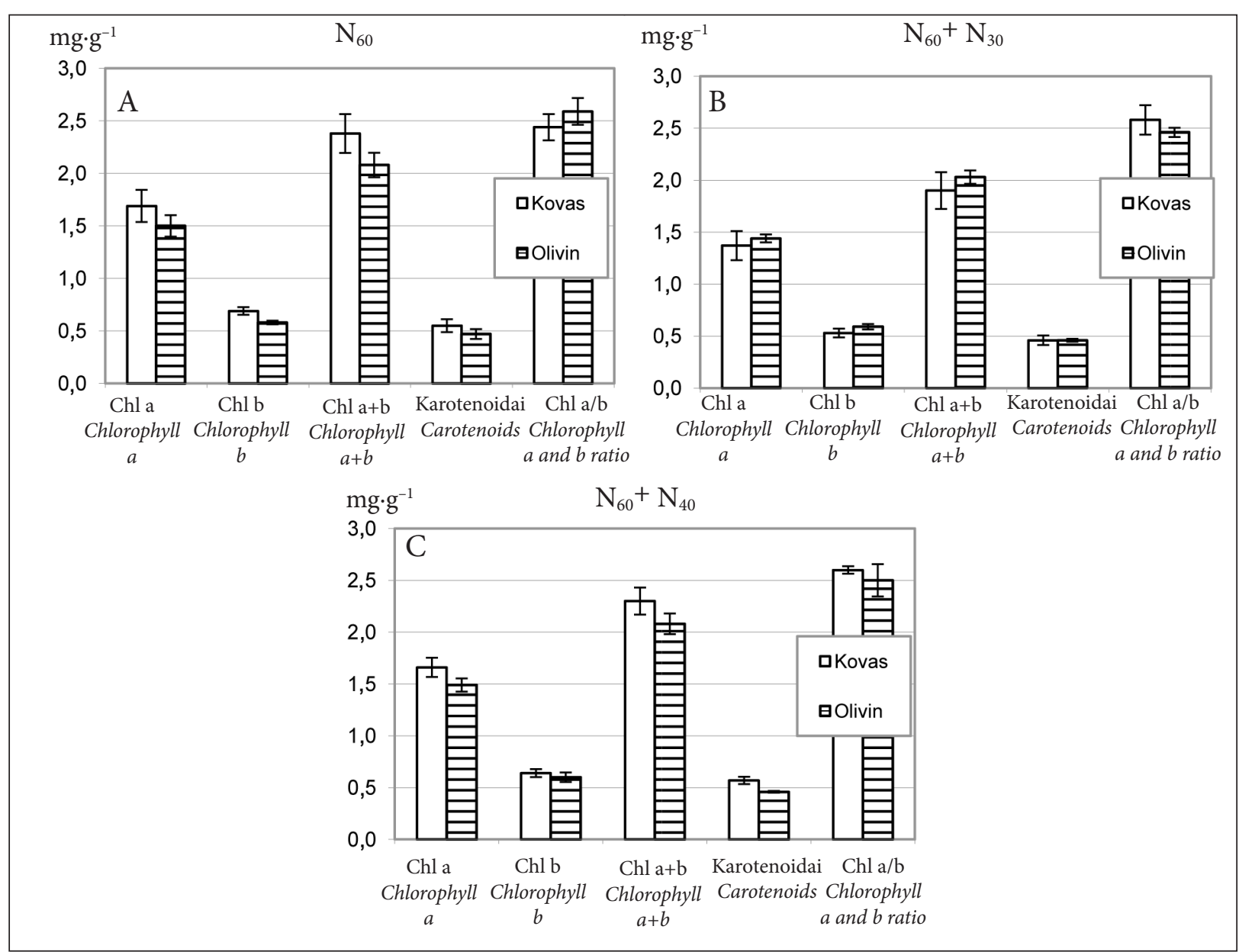

5 pav. Fotosintezès pigmentų kiekis žieminių kviečių lapuose po papildomo tręšimo (BBCH 38-41) karbamido tirpalais $\mathrm{N}_{30}$ ir $\mathrm{N}_{40}$

Fig. 5. The content of photosynthetic pigments in the winter wheat leaves after additional fertilization (BBCH 38-41) with urea solutions $N_{30}$ and $N_{40}$

Kontroliniuose ir $\mathrm{N}_{40}$ trąšų norma tręštuose laukeliuose augę 'Kovas' veislès kviečiai chlorofilo $a$ sukaupe $1,66-1,69 \mathrm{mg} \mathrm{g}^{-1}$, chlorofilo $b-0,64-$ $0,69 \mathrm{mg} \mathrm{g}^{-1}$, o 'Olivin' kviečiai chlorofilo $a-1,49-$

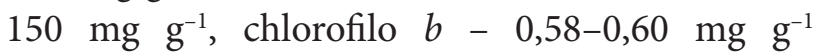
(5 pav. A, C). Didesnis karotenoidu kiekis nustatytas taip pat veislès 'Kovas' $\left(0,57 \mathrm{mg} \mathrm{g}^{-1}\right)$ augaluose, papildomam tręšimui panaudojus $\mathrm{N}_{40}$ trąšu normą, palyginti su 'Olivin' $\left(0,46 \mathrm{mg} \mathrm{g}^{-1}\right)$ veisle (5 pav. C). Bamblejjimo tarpsniu (BBCH 36) po papildomo tręšimo atlikta koreliacinè duomenų analizè parodè, kad tarp trąšų normų ir fotosintezès pigmentu yra silpna, neigiama priklausomybė ('Kovas' $-r=-0,42, P>0,05$; 'Olivin' $-r=-0,28$, $P>0,05)$. Papildomas tręšimas $\mathrm{N}_{30}$ ir $\mathrm{N}_{40}$ azoto normomis bamblejimo tarpsniu ( $\mathrm{BBCH} 36)$ lemiamos ittakos fotosintezès pigmentų kiekiui lapuose neturejo. Vadinasi, azoto mityba ir fotosin- tezès intensyvumas buvo pakankami, kadangi šiuo tarpsniu reikia daug fotosintezès proceso metu kuriamos energijos (5 pav. B, C).

Pieninès brandos tarpsniu (BBCH 71) prieš papildomą tręšimą $\mathrm{N}_{15}$ ir $\mathrm{N}_{30}$ azoto norma fotosintezès pigmentų daugiau sukaupe kviečių veislè 'Kovas' (6 pav.). Šiuo tarpsniu fotosintezès sistema dar intensyviai funkcionavo. Chlorofilo $a / b$ santykis priklausomai nuo trąšu normos kito nuo 2,70 iki 2,85 'Kovas' ir nuo 2,76 iki 2,93 'Olivin' kviečių veislių lapuose.

Chlorofilo $a, b$ ir karotenoidų kiekių, chlorofilu $a / b$ santykio skirtumai kviečių veislių 'Kovas' ir 'Olivin' augaluose naudojant skirtingas azoto normas buvo nedideli, išskyrus tą laukeli, kur kviečiai bamblèjimo tarpsniu (BBCH 36) papildomai tręšti $\mathrm{N}_{40}$ azoto norma (6 pav. E). Šiame laukelyje 'Kovas' (chlorofilas $b-0,84 \mathrm{mg} \mathrm{g}^{-1}$, karotenoidai $\left.-0,81 \mathrm{mg} \mathrm{g}^{-1}\right)$ 


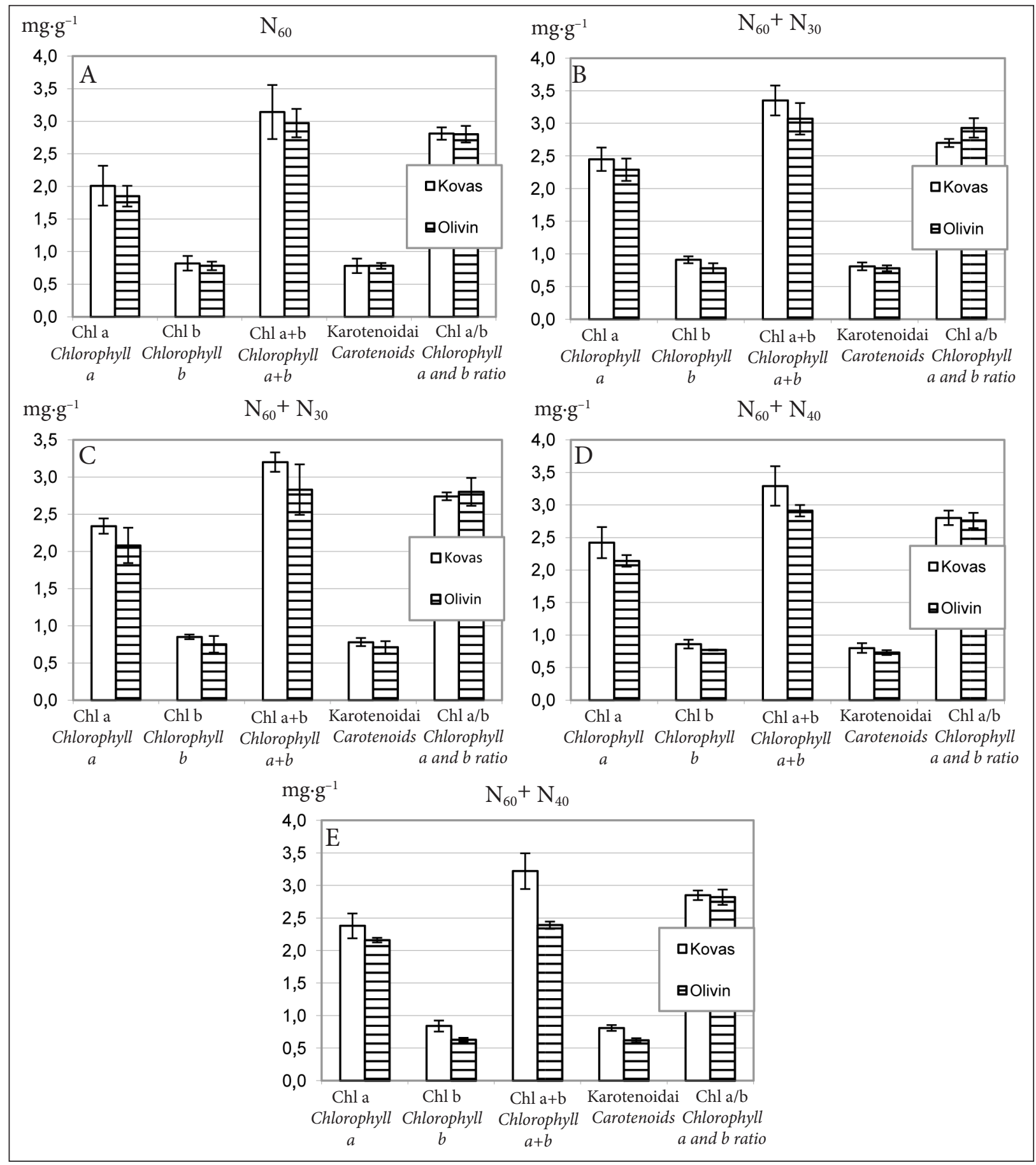

6 pav. Fotosintezės pigmentų kiekis žieminių kviečių lapuose prieš papildomą trę̌imą (BBCH 71-74) karbamido tirpalais $\mathrm{N}_{15}$ ir $\mathrm{N}_{30}$

Fig. 6. The content of photosynthetic pigments in the winter wheat leaves before additional fertilization (BBCH 71-74) with urea solutions $N_{15}$ and $N_{30}$

veislès kviečiai sukaupè didesni chlorofilo $b$ ir karotenoidu kieki nei 'Olivin' veislè (chlorofilas $b-0,63 \mathrm{mg} \mathrm{g}^{-1}$, karotenoidai - 0,62 $\left.\mathrm{mg} \mathrm{g}^{-1}\right)$. Pieninès brandos tarpsniu (BBCH 71) prieš papildomą tręšimą tarp trąšu normų ir 'Kovas' veislès augaluose sukaupto pigmentu kiekio nustatyta stipri, tiesiné teigiama priklausomybè $(r=0,62$,
$P>0,05)$, o tarp trąšų normų ir 'Olivin' augaluose sukaupto pigmentų kiekio - silpna, neigiama priklausomybè $(r=-0,45, P>0,05)$.

Pieninès brandos tarpsniu (BBCH 74) po papildomo tręšimo $\mathrm{N}_{15}, \mathrm{~N}_{30}$ azoto norma fotosintezès pigmentų kiekis buvo pradèjęs mažèti, o fotosintezès sistema pradejusi silpniau funkcionuoti (7 pav.). 


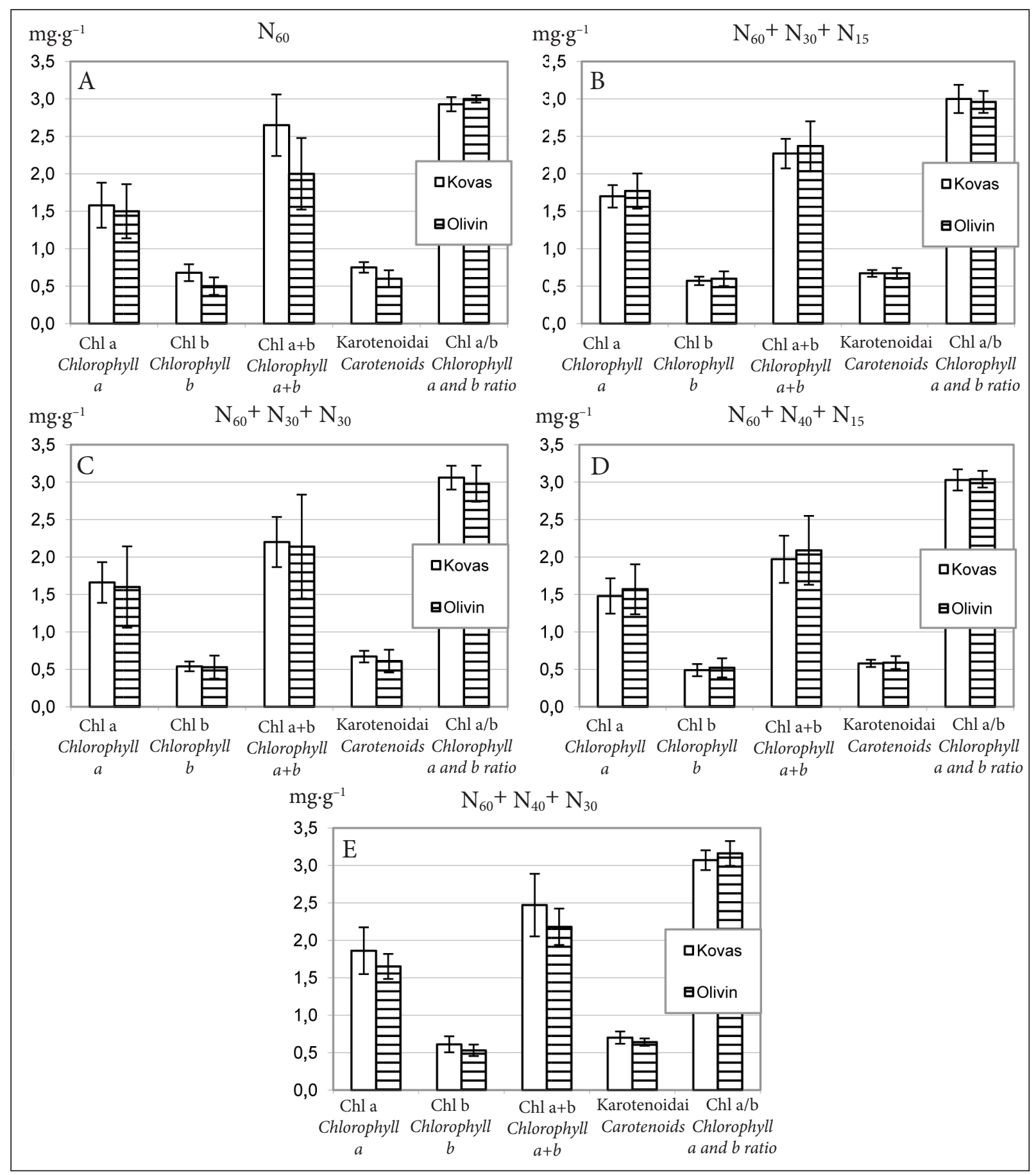

7 pav. Fotosintezès pigmentų kiekis žieminių kviečių lapuose po papildomo tręšimo (BBCH 75-76) karbamido tirpalais $\mathrm{N}_{15}$ ir $\mathrm{N}_{30}$

Fig. 7. The content of photosynthetic pigments in the winter wheat leaves after additional fertilization (BBCH 7576) with urea solutions $N_{15}$ and $N_{30}$

Chlorofilų $a / b$ santykis priklausomai nuo trąšų normos kito nuo 2,93 iki 3,07 'Kovas' ir nuo 2,96 iki 3,16 'Olivin' veislių lapuose. Chlorofilo $a, b$, karotenoidų kiekių, chlorofilų $a / b$ santykio skirtumai abiejų veislių augaluose naudojant skirtingas trąšu normas buvo nedideli. Pieninès brandos tarpsniu po papildomo tręšimo tarp trąšų normų ir fotosintezès pigmentų kiekio nustatyti koreliaciniai ryšiai. 'Kovas' veislès augaluose tarp trąšų normų ir sukaupto pigmentu kiekio nustatytas stiprus neigiamas ryšys ('Kovas' $-r=-0,58, P>0,05$ ), o 'Olivin' augaluose - silpnas, teigiamas $(r=0,45, P>0,05)$. 
Nustatyti fotosintezès pigmentų kiekiai nèra vienareikšmiškai tinkami trąšų įtakai vertinti. Augalų fiziologiniai procesai jautriai reaguoja iz bet kokius aplinkos sąlygų kitimus, todèl rezultatai atsispindi ne tik skirtingų azoto trąšų normų, bet ir aplinkos veiksnių poveikị (Tranavičienè, 2009).

Grynasis fotosintezès produktyvumas yra vienas iš svarbiausių fotosintezès rodiklių, atspindinčių tiek bendrą augalo būklę, tiek jo potencialą suformuoti derlių (Tranavičienè, 2009). Mūsų vykdytame eksperimente grynasis fotosintezès produktyvumas kito priklausomai nuo augimo tarpsnio ir trąšų normos (8, 9 pav.).

Buvo pastebimos ir kviečiu genotipo nulemtos tendencijos. Didesnès azoto trąšu normos 'Olivin' veislès kviečiuose šiek tiek padidino fotosintezès produktyvumą nuo vamzdelejjimo iki pieninès brandos tarpsnio (BBCH 43-74) $\left(2,2-3,2 \mathrm{mg} \mathrm{cm}^{-2}\right.$ per parą). Tarp trąšų normų ir 'Olivin' veislès produktyvumo nustatytas labai stiprus, teigiamas ryšys $(r=0,78, P>0,05)$. 'Kovas' veislès kviečiuose didesnès trąšų normos slopino fotosintezès produktyvumą (2,3-1,6 $\mathrm{mg} \mathrm{g}^{-2}$ per parą) $(r=0,06$, $P>0,05)$. Sèklos brendimo tarpsniu (BBCH 7477) 'Kovas' veislès augalai ilgiau išliko žali, todèl jų fotosintezès produktyvumas buvo didesnis. Didžiausias fotosintezès produktyvumas 'Kovas' veislès kviečiuose buvo nuo vamzdelèjimo iki pieninès brandos tarpsnio (BBCH 43-74), tręšiant $\mathrm{N}_{60}+\mathrm{N}_{30}$ azoto trąšų norma $\left(2,3 \mathrm{mg} \mathrm{cm}^{-2}\right.$ per parą). Intensyviausia kviečių veislès 'Olivin' fotosintezè vyko taip pat nuo vamzdelejjimo iki pieninès brandos tarpsnio (BBCH 43-74) tręšiant $\mathrm{N}_{60}+\mathrm{N}_{40}$ norma (3,2 $\mathrm{mg} \mathrm{cm}^{-2}$ per parą).

\section{REZULTATŲ APTARIMAS}

Azoto trąšos yra naudingos formuojant fotosintetini aparatą, palaikant chlorofilų $a$ ir $b$ santykį, užtikrinant efektyvią fotosintezę, tačiau fotosintezès pigmentų sudètis nèra pakankamai jautrus indikatorius nedidelių azoto normų skirtumų efektui įvertinti (Tranavičienè, 2009). Mūsų tyrimų rezultatai rodo, kad tirtų tręšimo normų pakako intensyviai fotosintezei ir pakankamam produktyvumui užtikrinti. Azoto normų skirtumai nebuvo tokie dideli, kad taip reikšmingai nulemtų fotosintezę (2-9 pav.). T. Tranavičienè ir kt. mokslininkai (2007) nustatè, kad bendram fotosintezès pigmentų kiekiui ịtakos turejjo trąšų normų didinimas. Atliekant mūsų eksperimentą nustatyta, kad nepriklausomai nuo tręšimo didesnès ịtakos fotosintezès pigmentams kaupti turejo veislès genetinès savybès. Didesnius pigmentų kiekius buvo linkusi kaupti kviečiu veislè 'Kovas', palyginti su veisle 'Olivin' (2-7 pav.). Daugiausia chlorofilo augalai

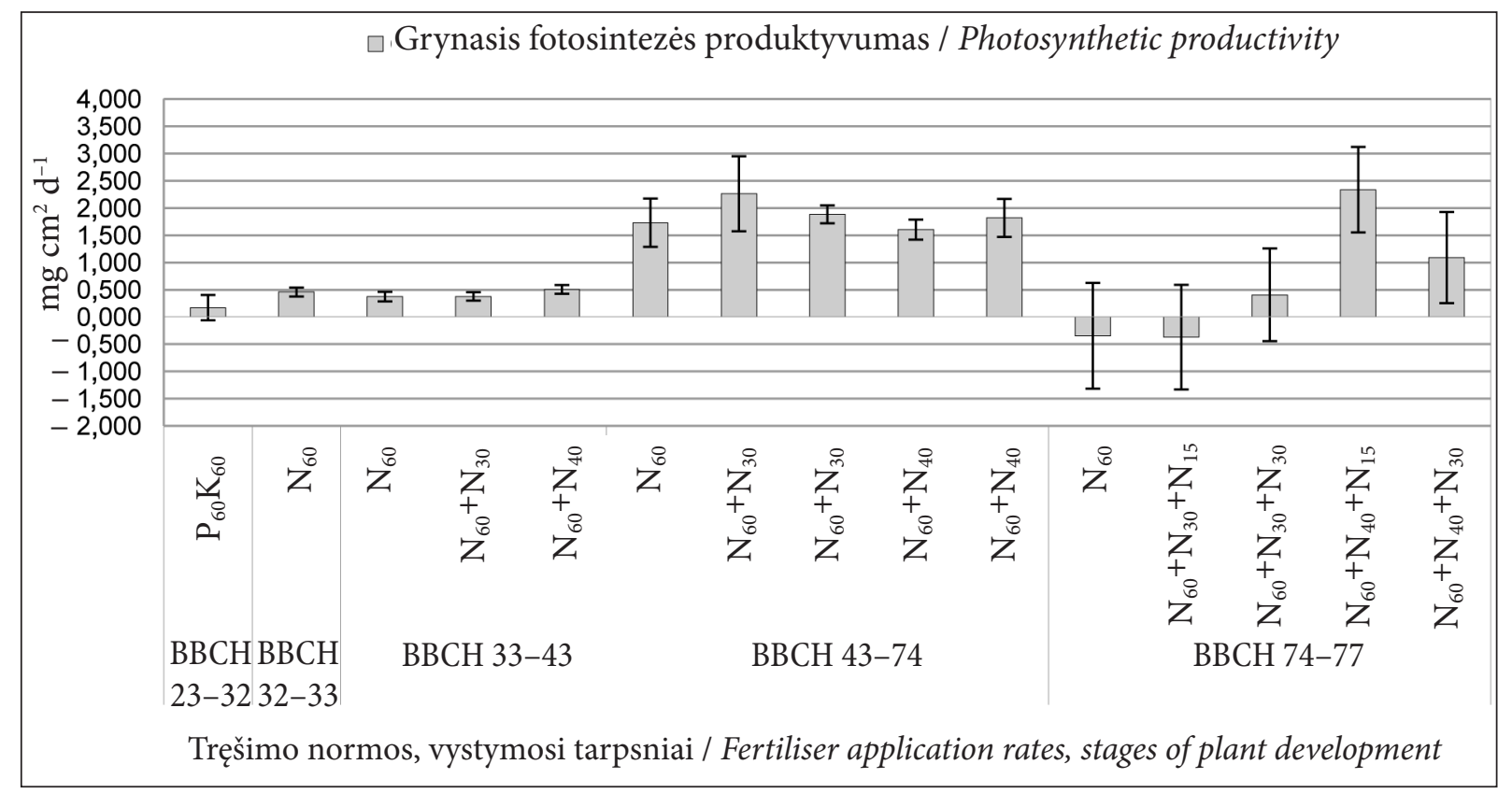

8 pav. Azoto trąšų ittaka 'Kovas' veislès žieminių kviečių grynajam fotosintezès produktyvumui Fig. 8. The effect of nitrogen fertilisers on photosynthetic productivity of the winter wheat of cultivar 'Kovas' 


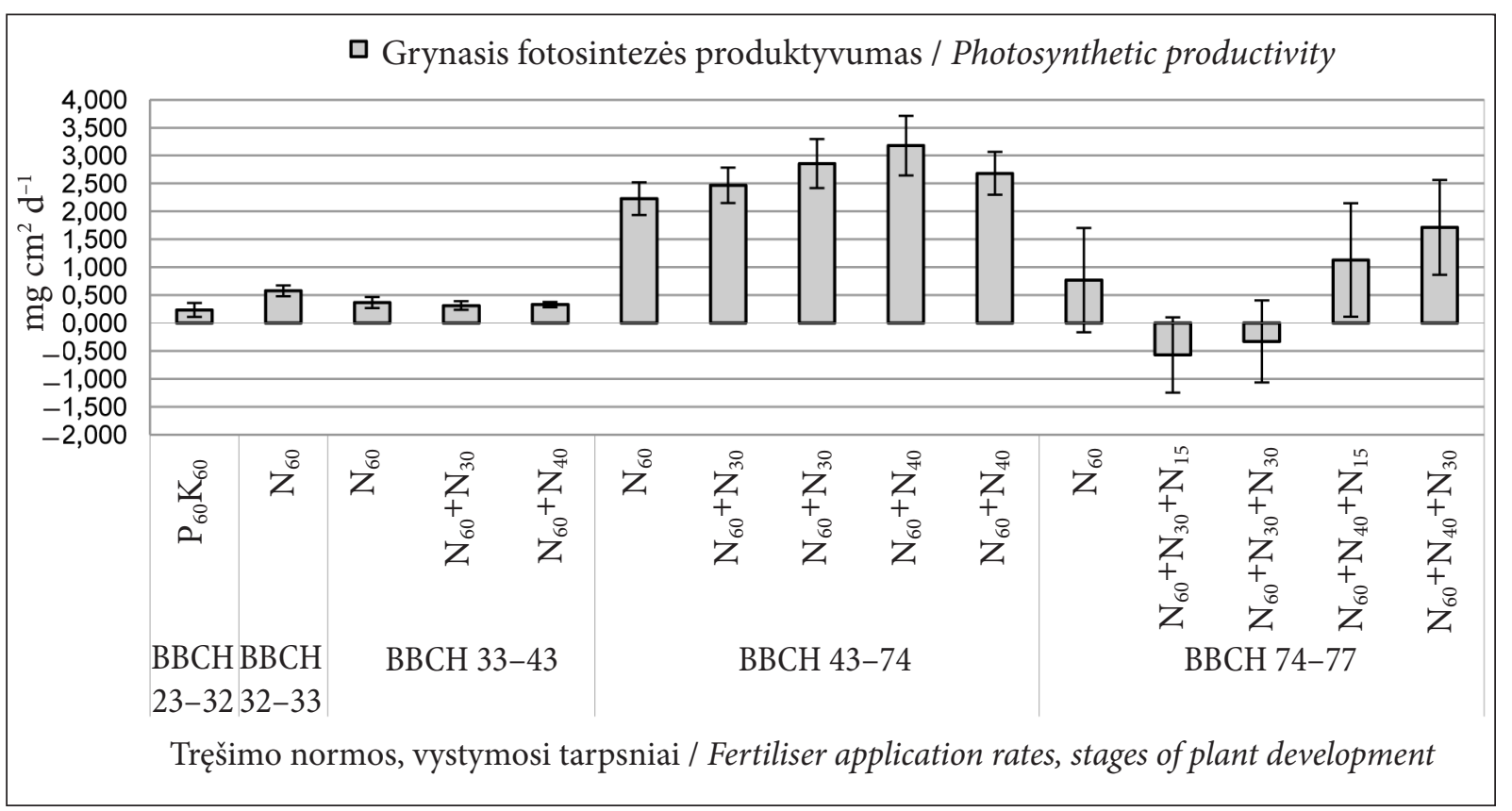

9 pav. Azoto trąšų įtaka 'Olivin' veislès žieminių kviečių grynajam fotosintezès produktyvumui

Fig. 9. The effect of nitrogen fertilisers on photosynthetic productivity of the winter wheat of cultivar 'Olivin'

sukaupia žydejjimo pradžioje, todèl teigiama, kad jis dalyvauja morfogenezès procesuose (Bojovic, Stojanovic, 2005; Samuolienè et al., 2007; Šlapakauskas, Duchovskis, 2008). A. Pečkytè (2009) savo tyrimuose nustatè, kad didžiausią chlorofilo $a$ kiekị salykliniai miežiai lapuose sukaupè plaukèjimo metu. Priešingai, mūsų tyrimais nustatyta, kad didžiausias pigmentų kiekis sukauptas pieninès brandos pradžioje (6 pav.). Papildomas tręšimas bamblejjimo tarpsniu šiek tiek padejo pristabdyti pigmentų degradaciją ir išlaikyti aktyvų fotosintezès veiklos periodą sèklų brendimo tarpsniu (7 pav.). Išanalizavus grynojo fotosintezès produktyvumo duomenis matyti, kad šis rodiklis kito priklausomai nuo augimo tarpsnio, trąšų normų bei veislès savybių. Naudotos didesnès trąšų normos nuo vamzdelejjimo iki pieninès brandos tarpsnio veislès 'Olivin' kviečiuose padidino fotosintezès produktyvumą, o 'Kovas' kviečiuose - sumažino. Didžiausias produktyvumas 'Olivin' veislès kviečiuose nustatytas nuo vamzdelèjimo iki pieninès brandos tarpsnio, tręšiant $\mathrm{N}_{60}+\mathrm{N}_{40}$ azoto norma, 'Kovas' kviečiuose $-\mathrm{N}_{60}+\mathrm{N}_{30}$ (8, 9 pav.). Kitų mokslininkų eksperimentuose su kitomis kviečių veislemis nustatyta, kad 'Ada' veislès fotosintezès produktyvumas, palyginti su veisle 'Seda', yra jautresnis tiek azoto trąšu normai, tiek skirtingoms meteorologinèms sąlygoms (Tranavičienè, 2009).

\section{IŠVADOS}

1. Papildomas tręšimas $\mathrm{N}_{30}, \mathrm{~N}_{40}$ azoto normomis vèlyvaisiais žieminių kviečių vystymosi tarpsniais lètina fotosintezès pigmentų degradaciją ir prailgina aktyvios fotosintezès periodą.

2. Žieminių kviečių veislè 'Kovas' kaupia didesnius fotosintezès pigmentų kiekius, palyginti su 'Olivin' veisle. Fotosintezės pigmentų didžiausias kiekis nustatytas pieninès brandos pradžioje.

3. Didžiausias fotosintezės produktyvumas nustatytas nuo vamzdelejjimo iki pieninès brandos tarpsnio (BBCH 43-74) veislès 'Kovas' augaluose tręšiant $\mathrm{N}_{60}+\mathrm{N}_{30}$, o ‘Olivin' augaluose $-\mathrm{N}_{60}+\mathrm{N}_{40}$.

Gauta 20150304 Priimta 20150330

\section{LITERATŪRA}

1. Balogh A., Hornok M., Pepo P. 2007. Study of physiological parameters in sustainable winter wheat (Triticum aestivum L.) production. Cereal Research Communications. No. 35. P. 205-208.

2. Bluzmanas P., Borusas S., Dagys J. 1991. Augalu fiziologija. Vilnius: Mokslas. $420 \mathrm{p}$.

3. Bojovic B., Stojanovic J. 2005. Chlorophyll and carotenoid content in wheat cultivars as a function of mineral nutrition. Archives of Biological Sciences. Vol. 57. P. 283-290. 
4. Brazaitytė A., Juknys R., Sakalauskaitė J., Sakalauskienė S., Lazauskas S., Kučinskienė E., Urbonavičiūtè A., Samuolienė G., Šabajevienė G., Ulinskaitè R., Kviklys D., Duchovskienė L., Šikniašnianienė J. B., Baranauskis K., Duchovskis P. 2008. Ekofiziologiniai tyrimai kintančios aplinkos sąlygomis. Sodininkyste ir daržininkysté. T. 27. Nr. 3. P. 263-276.

5. Cartelat A., Cerovic Z. G., Goulas Y., Meyer S., Lelarge C., Prioul J. L., Barbottin A., Jeuffroy M. H., Gate P., Agati G., Moya I. 2005. Optically assessed contents of leaf polyphenolics and chlorophyll as indicators of nitrogen deficiency in wheat (Triticum aestivum L.). Field Crop Research. Vol. 95. P. 31-39.

6. Diekmann F., Fishbeck G. 2005. Differences in wheat cultivar response to nitrogen supply. II: differences in N-metabolism related traits. Journal of Agronomy and Crop Science. Vol. 191. P. 362-376.

7. Duchovskis P., Brazaitytė A., Samuolienè G., Viršilè A., Vaštakaitė V. 2015. Fotofiziologiniu tyrimu būkle ir ju taikymo perspektyvos augalininkysteje: studija. Vilnius: LMA, $92 \mathrm{p}$.

8. Fritchi F. B., Ray J. D. 2007. Soybean leaf nitrogen, chlorophyll content, and chlorophyll a/b ratio. Photosynthetica. Vol. 45. P. 92-98.

9. Gavrilenko V. F., Zhygalova T. V. 2003. Bol'shoy praktikum po fotosintezu. Moskva. $256 \mathrm{~s}$.

10. Guo P., Baum M., Grando S., Ceccarelli S. 2006. Evaluation of chlorophyll content and fluorescence parameters as indicators of drought tolerance in barley. Agriculture Sciences in China. Vol. 5. Issue 10. P. 751-757.

11. Guo P., Baum M., Varshney R. K., Graner A., Grando S., Ceccarelli S. 2008. QTLs for chlorophyll and chlorophyll fluorescence parameters in barley under post-flowering drought. Euphytica. Vol. 162. No. 2. P. 203-214.

12. Houles V., Guerfi M., Mary B. 2007. Elaboration of a nitrogen nutrition indicator for winter wheat based on leaf area index and chlorophyll content for making nitrogen recommendations. European Journal of Agronomy. Vol. 27. P. 1-11.

13. Kichey T., Heumez E., Pocholle P., Pageau K., Vanacker H., Dubois F., Le Gouis J., Hirel B. 2006. Combined agronomic and physiological aspects of nitrogen management in wheat highlight a central role for glutamine synthetase. New Phytologist. Vol. 169. P. 265-278.

14. Kim S. H., Gitz D. C., Sicher R. C., Baker J. T., Timlin D. J., Reddy V. R. 2007. Temperature dependence of growth, development, and photosynthesis in maize under elevated $\mathrm{CO}_{2}$. Environmental and Experimental Botany. Vol. 61. P. 224-236.

15. Kopsell D. A., Kopsell D. E., Lefsrud M. G., Curran-Celentano J., Dukach L. E. 2004. Variation in lutein, $\beta$-carotene and chlorophyll concentrations among Brassica oleracea cultigens and seasons. Hortscience. Vol. 39. No. 2. P. 361-364.
16. Li L., Yu Q., Zheng Y., Wang J., Fang Q. 2006. Simulating the response of photosynthate partitioning during vegetative growth in winter wheat to environmental factors. Field Crops Research. Vol. 96. P. 133-141.

17. Lietuvos dirvožemiai: monografija. 2001. Vilnius: LMA. 1244 p.

18. Meier U. 1997. Growth Stages of Mono- and Dicotyledonous Plants. BBCH Monograph. Berlin, Wien: Blackwell Wissenschaftsverlag. 622 p.

19. Pečkytè A. 2009. Salyklinių miežių agrobiologinio potencialo bei derliaus kokybes priklausomumas nuo mineraliniu ir lapu trąšu: daktaro disertacija. Akademija, Kauno r. 139 p.

20. Sakalauskienė S., Brazaitytė A., Šabajevienė G., Lazauskas S., Sakalauskaitè J., Urbonavičiūtè A., Samuolienè G., Duchovskis P. 2009. Kompleksinis aplinkos veiksnių poveikis sejjamojo žirnio (Pisum sativum L.) fiziologiniams rodikliams organogenezès III-IV etapais. Zemdirbyste-Agriculture. T. 96. Nr. 3. P. 93-101.

21. Sakalauskienė S., Šabajevienè G., Lazauskas S., Brazaitytė A., Samuolienè G., Urbonavičiūtė A., Sakalauskaitė J., Ulinskaitė R., Duchovskis P. 2008. Skirtingo drègmès ir temperatūros rẻžimo kompleksinis poveikis ridikèlių fotosintetiniams rodikliams III-IV organogenezès etapuose. Sodininkystè ir daržininkystè. T. 27. Nr. 1. P. 97-104.

22. Samborski S. M., Tremblay N., Fallon E. 2009. Strategies to make use of plant sensors-based diagnostic information for nitrogen recommendations. Agronomy Journal. Vol. 101. P. 800-816.

23. Samuolienè G., Šabajevienè G., Urbonavičiūtė A., Duchovskis P. 2007. Carrot flowering initiation: light effect, photosynthetic pigments, carbohydrates. Acta Biologica Szegediensis. Vol. 51. No. 1. P. 39-42.

24. Scebba F., Soldatini G., Ranieri A. 2003. Ozone differentially affects and biochemical responses of two clover species: Trifolium repens and Trifolium oratense. Environmental Pollution. Vol. 123. No. 2. P. 209-216.

25. Sokal R. R., Rohlf F. J. 2000. Biometry. New York. $887 \mathrm{p}$.

26. Spaner D. M., Todd A. G., Navabi A., McKenzie D. B., Goonewardene L. A. 2005. Can leaf chlorophyll measures at differing growth stages be used as an indicator of winter wheat and spring barley nitrogen requirements in eastern Canada? Journal of Agronomy and Crop Science. Vol. 191. P. 393-399.

27. Šlapakauskas V., Duchovskis P. 2008. Augalu produktyvumas. Akademija, Kauno r. 253 p.

28. Tarakanovas P., Raudonius S. 2003. Agronominiu tyrimy duomenu statistine analize taikant kompiuterines programas ANOVA, STAT, SPLIT-PLOT iš paketo SELEKCIJA ir IRRISTAT. Akademija, Kauno r. 58 p. 
29. Tranavičienè T. 2009. Azoto poveikis skirtingu paprastojo kviečio (Triticum aestivum L.) veisliu fotosintezés ir grüdu kokybès rodikliams: daktaro disertacija. Akademija, Kauno r. 89 p.

30. TranavičienèT., ŠikšnianienėJ.B.,Urbonavičiūtè A., Vagusevičienè I., Samuolienè G., Duchovskis P., Sliesaravičius A. 2007. The effect of nitrogen fertilizers on wheat photosynthetic pigment and carbohydrate contents. Biologija. Vol. 53. No. 4. P. 8488.

31. Wingler A., Purdy S., MacLean J. A., Pourtau N. 2006. The role of sugars in integrating environmental signals during the regulation of leaf senescence. Journal of Experimental Botany. Vol. 57. P. 391-399.

\section{Aistė Juchnevičienė, Ilona Vagusevičienė, Aušra Kaminskaitė, Aušra Brazaitytė, Pavelas Duchovskis \\ THE EFFECT OF NITROGEN FERTILISERS FOR THE PHOTOSYNTHETIC INDICATORS OF DIFFERENT CULTIVARS OF WINTER WHEAT}

Summary

The work investigates the effect of nitrogen fertilisers on the dynamics of photosynthetic indicators of different cultivars of winter wheat. The field experiment was conducted in the period between 2012 and 2013 at the Experimental Station of Aleksandras Stulginskis University in carbonate shallow gleyic leached soil Calc(ar)i-Epihypogleyic Luvisol. The object of the investigation was the cultivars of winter wheat 'Kovas' and 'Olivin', which have good baking properties. During the sowing time the wheat was fertilized with single-element phosphorus and potassium $\mathrm{P}_{60} \mathrm{~K}_{60}$ fertiliser, and in spring, after the vegetation had renewed, the wheat was treated with ammonium nitrate $\mathrm{N}_{60}$. Additionally, foliar fertilizer urea solutions $\mathrm{N}_{30}$ and $\mathrm{N}_{40}$ at the booting stage and $\mathrm{N}_{15}$ and $\mathrm{N}_{40}$ at the milk ripening stage were applied. The investigation revealed that additional fertilization with $\mathrm{N}_{30}$ and $\mathrm{N}_{40}$ during the late stages of plant development induced the accumulation of photosynthetic pigments and prolonged the period of active photosynthesis. Genetic peculiarities of a certain cutivar had influence on the accumulation of pigments irrespective of treatment with nitrogen fertilisers. Cultivar 'Kovas', which has good baking properties, tends to accumulate larger amounts of photosynthetic pigments. The largest amount of pigments has been found in the wheat at the beginning of the milk ripening stage before additional fertilization with $\mathrm{N}_{15}$ and $\mathrm{N}_{30}$. The winter wheat of $\mathrm{cv}$. 'Olivin' has a higher potential for photosynthetic productivity than the winter wheat of cv. 'Kovas'. Photosynthesis was the most intensive in the plants of cv. 'Olivin' from the time when the flag leaf begins to grow to the milk ripening stage (BBCH 43-74) when they were fertilized with $\mathrm{N}_{60}+\mathrm{N}_{40}$, and in the wheat of $\mathrm{cv}$. 'Kovas' when they were treated with $\mathrm{N}_{60}$ and $\mathrm{N}_{30}$.

Key words: nitrogen fertilizer, photosynthetic pigments, photosynthetic productivity, cultivars of winter wheat 